vocabularies of their own. At many of the conferences, League of Nations representatives have been present. More and more the conferences are grouping themselves, and many conferences are being attended by representatives of other conferences. Such groups are the educational, agricultural and economic conferences. For example, the "Liaison Committee of Major International Associations" represents more than twenty-four international organisations, mostly educational. The economic conferences are not under the dictation of Governments. Between them these societies are working out a world-policy which is years ahead of the present League of Nations. The number of societies is increasing, and they are increasingly specialised. The International Council of Scientific Unions does not cover everything, although it is an authorised channel of communications. New societies of all sorts keep on appearing. All this apparatus of voluntary societies may be thought of as advisory to the official governmental League of Nations. Possibly it is more important that the politicians should listen to the scientific workers, rather than that the latter should let themselves be entangled in political machinations.

\section{Fig Mosaic}

A Leaf-Mottuing disease of the fig has been described from California and from Australia. The malady is caused by a virus, and is known as fig mosaic. Dr. G. C. Ainsworth announces the appearance of the disease in England (J. Roy. Hort. Soc., December 1935), and mentions two types of mottling, namely, irregular, yellowish-green blotches, and pale green spots or bands along the larger veins. The fruit is affected but slightly, with small spots. Now that botanists are 'virus-conscious', it has been realised that the disease was known twenty years ago, though its cause was not suspected, and it is fairly widespread in Great Britain.

\section{England to Cape Flight}

Mrs. Mollison arrived in Cape Town at 3.30 British Summer Time on May 7, having completed a flight from England in 3 days $6 \mathrm{hr}$. $25 \mathrm{~min}$. This time is a little more than eleven hours better than the previous record set up by Flight Lieutenant Rose, and represents a noteworthy achievement as regards endurance of both pilot and aeroplane. Mrs. Mollison flew over the West Coast route in Africa, and her machine was a Percival Gull with a Gipsy Six (120 h.p.) engine. It is stated in The Times that the distance covered was about 6,200 miles, with 43 hours flying and 36 hours on the ground. At the time of writing, Mrs. Mollison is well started on the return journey, but following the East Coast route.

\section{Institution of Electrical Engineers' Awards}

THE following awards of the Institution of Electrical Engineers have recently been made for papers read during 1935-36, or accepted for publication : Institution Premium to W. L. McPherson and
E. H. Ullrich; Ayrton Premium to Mr. G. H. Wilson, Lieut.-Commander E. L. Damant, and Mr. J. M. Waldram; Fahie Premium to Major L. H. Peter ; John Hopkinson Premium to D. R. Davies and C. H. Flurscheim; Kelvin Premium to Dr. T. E. Allibone and F. R. Perry ; Overseas Premiums to Dr. J. J. Rudra and D. J. Badkas, J. H. Sprawson and T. Varney; Extra Premiums to G. A. Whipple, A. L. Whiteley, Dr. Russell J. Reynolds, E. R. Kaan, B. G. Gates, E. T. Hippisley, A. C. Timmis, and Mr. R. Poole. Wirèless Section: Duddell Premium to H. L. Kirke and A. B. Howe; Extra Premiums to W. J. Brown and E. B. Moullin. Meter and Instrument Section: Silvanus Thompson Premium to J. H. Buchanan; Extra Premiums to Prof. J. T. MacGregor-Morris and R. M. Billington, J. S. Preston and G. A. Burns and T. R. Rayner. Transmission Section: Sebastian de Ferranti Premium to Mr. D. Ross; Extra Premium to Mr. J. S. Forrest.

\section{Conferences on Spectroscopy and Colour}

THE Massachusetts Institute of Technology has recently announced a special summer programme on applied physics, in connexion with which a conference on spectroscopy and its applications will be held on July 20-22, and a conference on colour on July 23-25. The former conference will include discussions on spectroscopic analysis of materials, and on other applications of spectroscopy to biology, medicine, chemistry, metallurgy, mineralogy and to industrial and engineering problems; the latter will include spectrophotometry, colorimetry, and the applications of colour measurements to industrial problems. Detailed consideration will be given to the behaviour and control of the colour of dyes and pigments, and their application in such fields as the paint, ink, paper, textile and ceramics industries. These conferences come at the conclusion of the courses on spectroscopic analysis of materials which are being given at the Institute during the six weeks from June 16 until July 24. There is no charge for attendance at the meetings of the conferences, copies of the detailed programmes of which will be sent on application to Prof. G. R. Harrison, Department of Physics, Massachusetts Institute of Technology, Cambridge, Massachusetts.

\section{Announcements}

Mr. C. H. Waddington, of the Strangeways Research Laboratory, and of the sub-department of experimental zoology of the University of Cambridge, has been awarded the Albert Brachet prize of the Royal Academy of Belgium for his experiments on chicken embryos. This was the first award of the prize, which is given for the best work in embryology published in French, German, English, Italian or Dutch over a three-year period.

THE field plots and laboratories of the Rothamsted Experimental Station, Harpenden, will be opened for inspection (by invitation) on June 11, at 11.15 a.m. The Right Hon. J. Ramsay Macdonald will be present. 